\title{
Early Childhood Caries: Epidemiology, Aetiology, and Prevention
}

\author{
F. Meyer $(i)$ and J. Enax \\ Research Department, Dr. Kurt Wolff GmbH \& Co. KG, Bielefeld, Germany \\ Correspondence should be addressed to F. Meyer; frederic.meyer@drwolffgroup.com \\ Received 19 March 2018; Revised 3 May 2018; Accepted 9 May 2018; Published 22 May 2018
}

Academic Editor: Ali I. Abdalla

Copyright (C) 2018 F. Meyer and J. Enax. This is an open access article distributed under the Creative Commons Attribution License, which permits unrestricted use, distribution, and reproduction in any medium, provided the original work is properly cited.

\begin{abstract}
Early childhood caries (ECC) is one of the most prevalent diseases in children worldwide. ECC is driven by a dysbiotic state of oral microorganisms mainly caused by a sugar-rich diet. Additionally, poor oral hygiene or insufficient dental plaque removal leads to the rapid progression of ECC. ECC leads not only to dental destruction and pain with children, but also affects the quality of life of the caregivers. Children with extensive ECC are at high risk to develop caries with the permanent dentition or will have other problems with speaking and/or eating. To prevent ECC, several strategies should be taken into account. Children should brush their teeth with toothpastes containing gentle ingredients, such as mild surfactants and agents showing antiadherent properties regarding oral microorganisms. Parents/caregivers have to help their children with brushing the teeth. Furthermore, remineralizing and nontoxic agents should be included into the toothpaste formulation. Two promising biomimetic agents for children's oral care are amorphous calcium phosphate $\left[\mathrm{Ca}_{x}\left(\mathrm{PO}_{4}\right)_{y} n \mathrm{H}_{2} \mathrm{O}\right]$ and hydroxyapatite $\left[\mathrm{Ca}_{5}\left(\mathrm{PO}_{4}\right)_{3}(\mathrm{OH})\right]$.
\end{abstract}

\section{Introduction}

Early childhood caries (ECC) is still one of the most prevalent diseases in children worldwide. ECC does not only affect children's oral health, but also the general health of children $[1,2]$. Not only oral pain, orthodontic problems, and enamel defects, but also problems with eating and speaking can occur as well as an increased risk for caries development in the permanent dentition [3]. Premature loss of primary dentition often leads to orthodontic problems in adult life [4]. Not only children are affected, but also parents will be influenced by this disease being the responsible caregivers [3,4]. For example, dental problems were shown to be the main reasons for hospitalisation of children in Australia in 2015 [5]. Thus, ECC leads not only to temporary pain, but more importantly has major effects on the quality of life of the family/caregivers including financial and health implications $[6,7]$. The aim of this review article is to present the state of the art of the epidemiology, aetiology, characteristics of primary dentition, risk factors, general recommendations, and strategies for prevention of ECC.

\section{Background and Epidemiology}

As stated before, ECC is still one of the most abundant diseases worldwide. The incidence of ECC among children with deciduous teeth is 1.76 billion (95\% CI: 1.26 billion; 2.39 billion) [8]. Interestingly, ECC is not limited to children with a low socioeconomic status (SES) $[9,10]$. Recent data, for example, from Australia show a prevalence of more than $50 \%$ of 6-year-old children with caries on deciduous teeth [5]. Data from different parts of the world show up to $89.2 \%$ of children with ECC in Qatar and 36\% in Greece [11, 12]. About the same prevalence (ca. 40\%) has been reported in the USA among 2-11 year old children [13]. A recently published study from Germany shows even 10\% (up to $26 \%$ with initial lesions) of 3-year-old children with ECC and an increase up to about $50 \%$ in 6-/7-year-old children [14]. Even though the dmft-index (decayed missing filled teeth) has decreased over time in general $[10,14]$, the prevalence has not decreased [14]. However, a study from Germany was also able to show different trajectories and an increase of $\mathrm{dmft}$-values when looking at a smaller scale on a regional level [10]. While most of the districts in a midsized German 
city showed a decrease of $\mathrm{dmft}$, the $\mathrm{dmft}$ increased in other districts over time [10]. Milsom et al. described that children with an already existing caries lesion have a 5-6 times higher incidence of developing new caries lesions compared to previously caries-free children [15]. Sleeping problems and insufficient sleep can also be identified as risk factor for ECC, as sleeping problems lead to a more frequent use of nighttime bottle use with sugar-sweetened beverages [16-18]. As the role of parents is still unclear with respect to their children developing ECC, several studies have focussed on different associations [19]. Sociocultural and socioeconomic backgrounds of the parents can be found as risk factors for ECC, but parental stress does not show a significant increase in ECC with the children $[10,19,20]$. Not only children, but also their parents should be motivated to take care of the primary dentition to prevent ECC and consequently further caries development in the secondary dentition [21].

\section{Aetiology of ECC}

Dental caries develops when the dental plaque, a polymicrobial biofilm, is not removed regularly and the diet consists of mainly monosaccharides. Monosaccharides can be metabolized by many of the oral bacteria leading to an increased production of acids which are able to demineralize the enamel $[22,23]$. Dental plaque is built on top of the pellicle starting directly after mechanical removal of the biofilm $[24,25]$. More than 700 bacterial species/taxa are known in the oral flora [26]. Because the oral habitat consists of many different ecological niches, the relatively high number of different species/taxa can be explained [27]. Oral microorganisms are able to interact with each other and mainly communicate using so-called "quorum sensing" (QS) [28]. Nowadays, it is well known that not only bacteria, but also fungi, such as Candida albicans and the interkingdom interactions, can enhance the progression of caries $[29,30]$. However, microorganisms grown in polyspecies biofilms are able to produce exopolysaccharides (EPS), also known as extracellular polymeric substances [31,32]. With the help of the EPS, microorganisms are able to resist antimicrobials that are recently used in toothpastes [32]. Consequently, biofilm formation is not interrupted and together with the absorbed saccharides from the diet leads to a cariogenic dental plaque [33]. The dental plaque on clinically sound enamel of children consists mainly of streptococci and actinomycetes [34]. With a low-sugar diet, these microorganisms are living as commensals in a homeostatic environment controlling each other [35]. As soon as sugars, especially sugary food and beverages, are consumed, the commensal plaque microbiota will absorb these saccharides and metabolize them into acids, mainly lactic acid [36]. This acid production leads to a $\mathrm{pH}$ shift from around 7 (neutral) to a $\mathrm{pH}<5.5$ (acidic) [37]. Acid-tolerant bacteria, mainly mutans streptococci, are able to survive these acidic environments [36]. When oral hygiene habits and nutritional habits do not change, a reduction of highly cariogenic microorganisms (mutans streptococci, Candida spp., and lactobacilli) cannot be achieved [38]. Peterson et al. used next-generation sequencing (NGS) to identify the microbial composition of the dental plaque. They show only slight differences between the biofilms collected from children with and without caries [39]: Streptococcus mitis and Streptococcus sanguinis were found in both groups. Streptococcus was found to be the most abundant genus ( $>50 \%$ of the microorganisms). Veillonella, Granulicatella, Fusobacterium, Neisseria, Campylobacter, Gemella, Abiotrophia, Selenomonas, and Capnocytophaga were also found in abundance between 1 and 10\% of the biofilm [39]. SimonSoro et al. also detected Lactobacillus-species, known as acidresistant bacteria, associated with caries [40, 41]. Even though the studies described above used NGS strategies, this technique is rapidly developing and recent studies are able to use even more sophisticated models predicting ECC [42]. Teng et al. used in vivo samples from a 3-year cohort study and showed, with the help of mathematical modelling, that $S$. mutans were not the main trigger for caries, but identified Veillonella spp. and Prevotella spp. instead [43]. Veillonella atypical, V. dispar, and V. parvula as well as Prevotella spp. were identified as bacteria that are mainly responsible for the development of ECC [43].

In conclusion, ECC develops as soon as the dental plaque is not removed adequately and a sugary diet, especially sweetened food and beverages, is consumed. This leads to a changing metabolism with the dental plaque microbiota producing mainly lactic acids that will demineralize the enamel. Prevotella spp. and Veillonella spp. were shown to be microbial risk factors, while together with fungi, bacteria can trigger acid metabolisms and virulence of the microorganisms $[29,30,41-43]$.

\section{Characteristics of Deciduous Enamel and Enamel of Permanent Teeth}

Enamel is the hardest tissue in the human body. It mainly consists of hydroxyapatite (97\%) (HAP), $\mathrm{Ca}_{5}\left(\mathrm{PO}_{4}\right)_{3}(\mathrm{OH})$, which is a calcium phosphate mineral [44-49]. Enamel is highly mineralized and has extraordinary mechanical properties $[44,45,47,50,51]$. The interior of a tooth consists of dentin (about 70\% HAP and 20\% proteins mainly collagen and $10 \%$ water), produced by odontoblasts, and the enamel, that is built by ameloblasts. Ameloblasts are restricted to produce enamel one time: ameloblasts produce several proteins and attract calcium and phosphate ions to crystallize these $[52,53]$. The enamel of deciduous teeth is built within a significantly shorter period (24 months) than permanent teeth (up to 16 years) [52]. The consequence of the shorter time for enamel development is the formation of a very thin enamel (half the thickness than that of the permanent teeth) and a less organized microstructure $[54,55]$. As consequence, acids are able to demineralize deciduous enamel faster than permanent enamel [56-58].

\section{Risk Factors}

ECC is known to be a multifactorial disease. Sugary food and beverages can lead to a dysbiotic state of the microbial composition causing caries. As ECC is also known as "baby bottle caries," feeding practices are noticed as main risk 
TABLE 1: Main ingredients for children's toothpastes (up to 6 years).

\begin{tabular}{|c|c|c|}
\hline Ingredient & Function/comments & References \\
\hline $\begin{array}{l}\text { Silica- or calcium carbonate-based abrasives with low } \\
\text { RDA value (RDA: radioactive dentin abrasion) }\end{array}$ & Plaque removal, gentle cleaning of deciduous teeth & {$[94]$} \\
\hline $\begin{array}{l}\text { Hydroxyapatite, ACP-CPP, fluorides in low } \\
\text { concentrations }\end{array}$ & Remineralization & {$[45,88]$} \\
\hline Hydroxyapatite & $\begin{array}{c}\text { Reduction of bacterial adhesion to enamel surfaces } \\
\text { due to antiadhesive properties }\end{array}$ & {$[82,84]$} \\
\hline Surfactants & $\begin{array}{c}\text { Foaming action, due to irritant properties, children's } \\
\text { toothpaste should not contain any sodium lauryl } \\
\text { sulfate (SLS) }\end{array}$ & [69] \\
\hline Preservatives/antimicrobial agents & $\begin{array}{l}\text { Due to risk of swallowing, children's toothpaste } \\
\text { should not contain any potent antimicrobial agents } \\
\text { such as chlorhexidine or triclosan, but mild } \\
\text { preservatives (e.g., alkanediols or xylitol as } \\
\text { antimicrobial agent) }\end{array}$ & {$[69,95]$} \\
\hline
\end{tabular}

factor developing ECC $[9,59,60]$. Here, the upper incisors and molars are affected at first, followed by the molars of the lower jaw and finally the lower jaw incisors [61]. Children sleeping with bottles filled with sweetened tea or milk containing several cariogenic sugars are at high risk for developing ECC. As a consequence of drinking during night time, without clearance of sugars, the oral bacteria will produce lactic acid rapidly, demineralizing the enamel $[9,62]$. Nowadays, not only baby bottles, but also several other sweetened juices consumed throughout the day or even at night will enhance the risk to develop caries. ECC is a disease affecting both low-SES families and high-SES families [9, 10]. However, unemployment and migration background can be found as risk factors for spatial disparities in ECC [10]. Other important factors that increase the risk to develop ECC are irregular toothbrushing (mechanical plaque removal) and/or toothbrushing without supervision by any caregivers [63]. Therefore, supervised thorough tooth brushing twice a day should be applied [64].

\section{General Recommendations}

The primary dentition usually erupts 6 to 8 months after birth [65]. As the oral cavity is highly sensitive, soft touches of the oral mucosa and gingiva should be performed in the early infant life to get the infants used to tooth brushing. Tooth brushing of at least two to three minutes should be performed two times a day by the caregivers as soon as the first tooth erupts [65]. Most dentists recommend to use a "pea-size" amount of a fluoride toothpaste for children, which contain usually not more than 500 ppm fluoride [66]. Additionally, fluoride gels could be used [67]. However, adverse effects like fluorosis need to include assessment of potential adverse effects [67].

\section{Biomimetic Concepts and Tooth Brushing to Prevent ECC}

It is well known that fluorides and especially fluoridated toothpastes may have a beneficial effect inhibiting caries progression [68]. However, an average caries reduction of
$23 \%$ compared to a placebo can only be detected using toothpastes containing a minimum of $1000 \mathrm{ppm}(0.1 \%)$ fluoride. In Europe as well as other parts of the world, toothpastes for children should contain a maximum of $500 \mathrm{ppm}(0.05 \%)$ fluoride $[66,69]$. Toothpastes with more than $1000 \mathrm{ppm}$ fluoride to $1500 \mathrm{ppm}$ fluoride have to be labelled in the EU as "Children of 6 years and younger: Use a pea sized amount for supervised brushing to minimize swallowing. In the case of fluoride intake from other sources consult a dentist or doctor" [70]. Other countries have similar restrictions and warnings. The reason is an enhanced risk for dental fluorosis and skeletal fluorosis due to the accumulation of fluoride from different sources and swallowing the fluoridated toothpaste [66]. Additionally, it is discussed whether fluorides interact with ameloblasts and have negative impact on the enamel formation [53, 71]. Fluorides are mainly functioning due to topical application by enhancing remineralization with calcium and phosphate ions derived from saliva [72]. Consequently, intake of fluoride tablets and fluoridated salts are discussed whether to be effective in caries protection or not [66]. In the past, it was assumed that fluorides lead to the formation of fluoroapatite $\left[\mathrm{Ca}_{5}\left(\mathrm{PO}_{4}\right)_{3} \mathrm{~F}\right]$. This mechanism was thought to make teeth more resistant to acids and protect the enamel. However, only small amounts of fluorapatite can be detected [50,73-75]. Interestingly, fluorotic teeth with higher concentration of fluoride are even less resistant to acids than sound enamel [75-77].

Alternatives to prevent caries and especially ECC in children need to be based on biomimetic strategies. Several products based on different calcium phosphates are already on the market and well studied [78]. Besides others, hydroxyapatite (HAP) $\left[\mathrm{Ca}_{5}\left(\mathrm{PO}_{4}\right)_{3}(\mathrm{OH})\right]$ and amorphous calcium phosphates $\left[\mathrm{Ca}_{x}\left(\mathrm{PO}_{4}\right)_{y} \cdot n \mathrm{H}_{2} \mathrm{O}\right]$ stabilized by casein proteins (CPP-ACP) show the most promising results. HAP was identified to be very effective in preventing ECC within a cohort of Japanese children following a 3-year study which showed a reduction of new caries lesions of up to $56 \%$ $[69,79]$. A recently published randomized, double-blind clinical study shows that microcrystalline HAP is not inferior to fluorides in clinical caries prevention [80]. Besides 
remineralizing properties that are equal to sodium fluoride [81], HAP-microclusters were shown to reduce dental plaque formation in situ and in vivo [82-86]. Lelli et al. were able to observe a protective layer on the top of enamel after using HAP-toothpaste in vivo [87]. Similar results can be found when using CPP-ACP. This calcium phosphate is also able to remineralize initial enamel lesions equivalent to fluorides [88]. Different studies showed that early lesions can also be remineralized and regressed using CPP-ACP [89] and regarding remineralization identified CPP-ACP to even be superior to a high fluoride containing product (5000 ppm fluoride) [90]. However, others studies have shown contrary results $[91,92]$.

Besides remineralizing ingredients, toothpastes should have biofilm controlling properties that do not affect children's health [93] (Table 1).

The use of an appropriate toothpaste should be accompanied by twice daily supervised/supported tooth brushing as well as regular visits to the dentist (at least once a year) [96]. With respect to the motor abilities of very young children, brushing should be carried out using electric brushes or manual toothbrushes especially made for children under parental supervision [97]. Even though there are several brushing techniques known, for younger children, the horizontal brushing technique is recommended combined with a 3-minute brushing period [98]. Paediatricians should also check both the oral health and fluoride anamnese of the children while also asking the parents about the child's oral hygiene. Toothbrushes should be replaced every 3 months or when the bristles become frayed with use [99].

\section{Conclusion}

In additionally to a low sugary diet, children should brush their teeth twice a day under parental supervision and be supported with brushing. The caregivers should especially support very young children (under the age of 3) continuously. Toothpastes should mainly comprise promising remineralizing agents for children's oral care such as calcium phosphates like CPP-ACP or HAP.

\section{Conflicts of Interest}

The authors declare no conflicts of interest.

\section{Acknowledgments}

The authors would like to thank Dr. Barbara Simader, a dentist, for the helpful discussions.

\section{References}

[1] R. Naidu, J. Nunn, and E. Donnelly-Swift, "Oral health-related quality of life and early childhood caries among preschool children in Trinidad," BMC Oral Health, vol. 16, no. 1, p. 128, 2016.

[2] S. L. Filstrup, D. Briskie, M. da Fonseca, L. Lawrence, A. Wandera, and M. R. Inglehart, "Early childhood caries and quality of life: child and parent perspectives," Pediatric Dentistry, vol. 25, no. 5, pp. 431-440, 2003.
[3] J. Abanto, T. S. Carvalho, F. M. Mendes, M. T. Wanderley, M. Bonecker, and D. P. Raggio, "Impact of oral diseases and disorders on oral health-related quality of life of preschool children," Community Dentistry and Oral Epidemiology, vol. 39, no. 2, pp. 105-114, 2011.

[4] P. S. Casamassimo, S. Thikkurissy, B. L. Edelstein, and E. Maiorini, "Beyond the dmft: the human and economic cost of early childhood caries," Journal of the American Dental Association, vol. 140, no. 6, pp. 650-657, 2009.

[5] S. Chrisopoulos and J. E. Harford, Oral Health and Dental Care in Australia: Key Facts and Figures 2015, Australian Institute of Health and Welfare and the University of Adelaide, Canberra, ACT, Australia, 2016.

[6] A. J. Righolt, M. Jevdjevic, W. Marcenes, and S. Listl, "Global-, regional-, and country-level economic impacts of dental diseases in 2015," Journal of Dental Research, vol. 97, no. 5, pp. 501-507, 2018.

[7] A. BaniHani, C. Deery, J. Toumba, T. Munyombwe, and M. Duggal, "The impact of dental caries and its treatment by conventional or biological approaches on the oral healthrelated quality of life of children and carers," International Journal of Paediatric Dentistry, vol. 28, no. 2, pp. 266-276, 2017.

[8] T. Vos, A. A. Abajobir, K. H. Abate et al., "Global, regional, and national incidence, prevalence, and years lived with disability for 328 diseases and injuries for 195 countries, 1990-2016: a systematic analysis for the Global Burden of Disease Study," The Lancet, vol. 390, no. 10100, pp. 1211-1259, 2016.

[9] H. Colak, C. T. Dulgergil, M. Dalli, and M. M. Hamidi, "Early childhood caries update: a review of causes, diagnoses, and treatments," Journal of Natural Science, Biology, and Medicine, vol. 4, no. 1, pp. 29-38, 2013.

[10] F. Meyer, A. Karch, K. M. Schlinkmann et al., "Sociodemographic determinants of spatial disparities in early childhood caries: an ecological analysis in Braunschweig, Germany," Community Dentistry and Oral Epidemiology, vol. 45, no. 5, pp. 442-448, 2017.

[11] A. Alkhtib, A. Ghanim, M. Temple-Smith, L. B. Messer, M. Pirotta, and M. Morgan, "Prevalence of early childhood caries and enamel defects in four and five-year old Qatari preschool children," BMC Oral Health, vol. 16, p. 73, 2016.

[12] C. J. Oulis, K. Tsinidou, G. Vadiakas, E. Mamai-Homata, A. Polychronopoulou, and T. Athanasouli, "Caries prevalence of 5, 12 and 15-year-old Greek children: a national pathfinder survey," Community Dental Health, vol. 29, no. 1, pp. 29-32, 2012.

[13] B. A. Bugis, "Early childhood caries and the impact of current U.S. Medicaid program: an overview," International Journal of Dentistry, vol. 2012, Article ID 348237, 7 pages, 2012.

[14] R. Basner, R. M. Santamaría, J. Schmoeckel, E. Schüler, and C. Splieth, Epidemiologische Begleituntersuchungen zur Gruppenprophylaxe 2016, DAJ-Deutsche Arbeitsgemeinschaft für Jugendzahnpflege e. V, Bonn, Germany, 2018.

[15] K. M. Milsom, A. S. Blinkhorn, and M. Tickle, "The incidence of dental caries in the primary molar teeth of young children receiving National Health Service funded dental care in practices in the North West of England," British Dental Journal, vol. 205, p. E14, 2008.

[16] S. D. Shantinath, D. Breiger, B. J. Williams, and J. E. Hasazi, "The relationship of sleep problems and sleep-associated feeding to nursing caries," Pediatric Dentistry, vol. 18, no. 5, pp. 375-378, 1996. 
[17] H. Chen, S. Tanaka, K. Arai, S. Yoshida, and K. Kawakami, "Insufficient sleep and incidence of dental caries in deciduous teeth among children in Japan: a population-based cohort study," Journal of Pediatrics, pii: S0022-3476(18)30380-9, 2018.

[18] I. Kraljevic, C. Filippi, and A. Filippi, "Risk indicators of early childhood caries (ECC) in children with high treatment needs," Swiss Dental Journal, vol. 127, no. 5, pp. 398-410, 2017.

[19] M. Hooley, H. Skouteris, C. Boganin, J. Satur, and N. Kilpatrick, "Parental influence and the development of dental caries in children aged 0-6 years: a systematic review of the literature," Journal of Dentistry, vol. 40, no. 11, pp. 873$885,2012$.

[20] S. E. Jabbarifar, N. Ahmady, S. A. R. Sahafian, F. Samei, and S. Soheillipour, "Association of parental stress and early childhood caries," Dental Research Journal, vol. 6, no. 2, pp. 65-70, 2009.

[21] K. Narksawat, A. Boonthum, and U. Tonmukayakul, "Roles of parents in preventing dental caries in the primary dentition among preschool children in Thailand," Asia-Pacific Journal of Public Health, vol. 23, no. 2, pp. 209-216, 2011.

[22] V. Zijnge, M. B. van Leeuwen, J. E. Degener et al., "Oral biofilm architecture on natural teeth," PLoS One, vol. 5, no. 2, article e9321, 2010.

[23] F. Meyer and J. Enax, "Die mundhöhle als ökosystem," Biologie in Unserer Zeit, vol. 48, no. 1, pp. 62-68, 2018.

[24] B. Rosan and R. J. Lamont, "Dental plaque formation," Microbes and Infection, vol. 2, no. 13, pp. 1599-1607, 2000.

[25] R. Huang, M. Li, and R. L. Gregory, "Bacterial interactions in dental biofilm," Virulence, vol. 2, no. 5, pp. 435-444, 2011.

[26] D. Verma, P. K. Garg, and A. K. Dubey, "Insights into the human oral microbiome," Archives of Microbiology, vol. 200, no. 4, pp. 525-540, 2018.

[27] X. Xu, J. He, J. Xue et al., "Oral cavity contains distinct niches with dynamic microbial communities," Environmental Microbiology, vol. 17, no. 3, pp. 699-710, 2015.

[28] Y.-H. Li and X. Tian, "Quorum sensing and bacterial social interactions in biofilms," Sensors, vol. 12, no. 3, pp. 2519-2538, 2012.

[29] H. Sztajer, S. P. Szafranski, J. Tomasch et al., "Cross-feeding and interkingdom communication in dual-species biofilms of Streptococcus mutans and Candida albicans," ISME Journal, vol. 8, no. 11, pp. 2256-2271, 2014.

[30] M. L. Falsetta, M. I. Klein, P. M. Colonne et al., "Symbiotic relationship between Streptococcus mutans and Candida albicans synergizes virulence of plaque biofilms in vivo," Infection and Immunity, vol. 82, no. 5, pp. 1968-1981, 2014.

[31] T. T. More, J. S. Yadav, S. Yan, R. D. Tyagi, and R. Y. Surampalli, "Extracellular polymeric substances of bacteria and their potential environmental applications," Journal of Environmental Management, vol. 144, pp. 1-25, 2014.

[32] H. Koo, M. L. Falsetta, and M. I. Klein, "The exopolysaccharide matrix: a virulence determinant of cariogenic biofilm," Journal of Dental Research, vol. 92, no. 12, pp. 1065-1073, 2013.

[33] P. Lingstrom, F. O. van Ruyven, J. van Houte, and R. Kent, "The $\mathrm{pH}$ of dental plaque in its relation to early enamel caries and dental plaque flora in humans," Journal of Dental Research, vol. 79, no. 2, pp. 770-777, 2000.

[34] N. Takahashi and B. Nyvad, "The role of bacteria in the caries process: ecological perspectives," Journal of Dental Research, vol. 90, no. 3, pp. 294-303, 2011.
[35] M. Kilian, I. L. C. Chapple, M. Hannig et al., "The oral microbiome-an update for oral healthcare professionals," British Dental Journal, vol. 221, no. 10, pp. 657-666, 2016.

[36] R. Touger-Decker and C. van Loveren, "Sugars and dental caries," American Journal of Clinical Nutrition, vol. 78, no. 4, pp. 881S-892S, 2003.

[37] I. Struzycka, "The oral microbiome in dental caries," Polish Journal of Microbiology, vol. 63, no. 2, pp. 127-135, 2014.

[38] T. Klinke, M. Urban, C. Luck, C. Hannig, M. Kuhn, and N. Kramer, "Changes in Candida spp., mutans streptococci and lactobacilli following treatment of early childhood caries: a 1-year follow-up," Caries Research, vol. 48, no. 1, pp. 24-31, 2014.

[39] S. N. Peterson, T. Meissner, A. I. Su et al., "Functional expression of dental plaque microbiota," Frontiers in Cellular and Infection Microbiology, vol. 4, p. 108, 2014.

[40] A. Simon-Soro, I. Tomas, R. Cabrera-Rubio, M. D. Catalan, B. Nyvad, and A. Mira, "Microbial geography of the oral cavity," Journal of Dental Research, vol. 92, no. 7, pp. 616-621, 2013.

[41] A. Simon-Soro and A. Mira, "Solving the etiology of dental caries," Trends in Microbiology, vol. 23, no. 2, pp. 76-82, 2015.

[42] E. Hajishengallis, Y. Parsaei, M. I. Klein, and H. Koo, "Advances in the microbial etiology and pathogenesis of early childhood caries," Cell Host \& Microbe, vol. 32, no. 1, pp. 24-34, 2017.

[43] F. Teng, F. Yang, S. Huang et al., "Prediction of early childhood caries via spatial-temporal variations of oral microbiota," Cell Host \& Microbe, vol. 18, no. 3, pp. 296-306, 2015.

[44] S. V. Dorozhkin and M. Epple, "Biological and medical significance of calcium phosphates," Angewandte Chemie International Edition, vol. 41, no. 17, pp. 3130-3146, 2002.

[45] J. Enax and M. Epple, "Synthetic hydroxyapatite as a biomimetic oral care agent," Oral Health \& Preventive Dentistry, vol. 16, no. 1, pp. 7-19, 2018.

[46] P. W. Brown and B. Constantz, Hydroxyapatite and Related Materials, CRC Press, Boca Raton, FL, USA, 1994.

[47] H. A. Lowenstam and S. Weiner, On Biomineralization, Oxford University Press, Oxford, UK, 1989.

[48] M. F. Teaford, M. M. Smith, and M. W. J. Ferguson, Development, Function and Evolution of Teeth, Cambridge University Press, Cambridge, UK, 2000.

[49] M. S. Tung and D. Skrtic, "Interfacial properties of hydroxyapatite, fluoroapatite and octacalcium phosphate," Monographs in Oral Science, vol. 18, pp. 112-129, 2001.

[50] J. Enax, O. Prymak, D. Raabe, and M. Epple, "Structure, composition, and mechanical properties of shark teeth," Journal of Structural Biology, vol. 178, no. 3, pp. 290-299, 2012.

[51] E. D. Yilmaz, S. Bechtle, H. Özcoban, A. Schreyer, and G. A. Schneider, "Fracture behavior of hydroxyapatite nanofibers in dental enamel under micropillar compression," Scripta Materialia, vol. 68, no. 6, pp. 404-407, 2013.

[52] K.-J. Moll and M. Moll, Kurzlehrbuch Anatomie, Elsevier, New York, NY, USA, 2000.

[53] C. E. Smith, R. Wazen, Y. Hu et al., "Consequences for enamel development and mineralization resulting from loss of function of ameloblastin or enamelin," European Journal of Oral Sciences, vol. 117, no. 5, pp. 485-497, 2009.

[54] M. A. De Menezes Oliveira, C. P. Torres, J. M. Gomes-Silva et al., "Microstructure and mineral composition of dental enamel of permanent and deciduous teeth," Microscopy Research and Technique, vol. 73, no. 5, pp. 572-577, 2010. 
[55] A. Lucchese and E. Storti, "Morphological characteristics of primary enamel surfaces versus permanent enamel surfaces: SEM digital analysis," European Journal of Paediatric Dentistry, vol. 12, no. 3, pp. 179-183, 2011.

[56] P. R. Wilson and A. D. Beynon, "Mineralization differences between human deciduous and permanent enamel measured by quantitative microradiography," Archives of Oral Biology, vol. 34, no. 2, pp. 85-88, 1989.

[57] M. C. Z. Alcantara-Galeana, R. Contreras-Bulnes, L. E. Rodríguez-Vilchis et al., "Microhardness, structure, and morphology of primary enamel after phosphoric acid, selfetching adhesive, and Er:YAG laser etching," International Journal of Optics, vol. 2017, Article ID 7634739, 8 pages, 2017.

[58] C. M. Zamudio-Ortega, R. Contreras-Bulnes, R. J. ScougallVilchis, R. A. Morales-Luckie, O. F. Olea-Mejia, and L. E. Rodriguez-Vilchis, "Morphological, chemical and structural characterisation of deciduous enamel: SEM, EDS, XRD, FTIR and XPS analysis," European Journal of Paediatric Dentistry, vol. 15, no. 3, pp. 275-280, 2014.

[59] S. Anil and P. S. Anand, "Early childhood caries: prevalence, risk factors, and prevention," Frontiers in Pediatrics, vol. 5, p. 157, 2017.

[60] C. A. Feldens, P. H. Rodrigues, G. de Anastacio, M. R. Vitolo, and B. W. Chaffee, "Feeding frequency in infancy and dental caries in childhood: a prospective cohort study," International Dental Journal, vol. 68, no. 2, pp. 113-121, 2017.

[61] A. H. Wyne, "Early childhood caries: nomenclature and case definition," Community Dentistry and Oral Epidemiology, vol. 27, no. 5, pp. 313-315, 1999.

[62] W. M. Avila, I. A. Pordeus, S. M. Paiva, and C. C. Martins, "Breast and bottle feeding as risk factors for dental caries: a systematic review and meta-analysis," PLoS One, vol. 10, no. 11, article e0142922, 2015.

[63] P. Prakash, P. Subramaniam, B. H. Durgesh, and S. Konde, "Prevalence of early childhood caries and associated risk factors in preschool children of urban Bangalore, India: a cross-sectional study," European Journal of Dentistry, vol. 6, no. 2, pp. 141-152, 2012.

[64] R. J. Berkowitz, "Causes, treatment and prevention of early childhood caries: a microbiologic perspective," Journal of the Canadian Dental Association, vol. 69, no. 5, pp. 304-307, 2003.

[65] "Tooth eruption," Journal of the American Dental Association, vol. 137, no. 1, p. 127, 2006.

[66] H. Limeback and C. Robinson, "Fluoride therapy," in Comprehensive Preventive Dentistry, pp. 251-282, John Wiley \& Sons, Ltd., Hoboken, NY, USA, 2012.

[67] V. C. Marinho, H. V. Worthington, T. Walsh, and L. Y. Chong, "Fluoride gels for preventing dental caries in children and adolescents," Cochrane Database of Systematic Reviews, vol. 6, p. CD002280, 2015.

[68] T. Walsh, H. V. Worthington, A. M. Glenny, P. Appelbe, V. C. Marinho, and X. Shi, "Fluoride toothpastes of different concentrations for preventing dental caries in children and adolescents," Cochrane Database of Systematic Reviews, vol. 1, p. Cd007868, 2010.

[69] C. V. Loveren, Toothpastes, Vol. 23, Karger Publishers, Basel, Switzerland, 2013.

[70] European Academy of Paediatric Dentistry, "Guidelines on the use of fluoride in children: an EAPD policy document," European Archives of Paediatric Dentistry, vol. 10, no. 3, pp. 129-135, 2009.

[71] A. L. Bronckers, D. M. Lyaruu, and P. K. DenBesten, "The impact of fluoride on ameloblasts and the mechanisms of enamel fluorosis," Journal of Dental Research, vol. 88, no. 10, pp. 877-893, 2009.

[72] J. M. ten Cate, "Review on fluoride, with special emphasis on calcium fluoride mechanisms in caries prevention," European Journal of Oral Sciences, vol. 105, no. 5, pp. 461-465, 1997.

[73] J. A. Weatherell, C. Robinson, and A. S. Hallsworth, "Changes in the fluoride concentration of the labial enamel surface with age," Caries Research, vol. 6, no. 4, pp. 312-324, 1972.

[74] F. Muller, C. Zeitz, H. Mantz et al., "Elemental depth profiling of fluoridated hydroxyapatite: saving your dentition by the skin of your teeth?," Langmuir, vol. 26, no. 24, pp. 1875018759, 2010.

[75] F. Neues, A. Klocke, F. Beckmann, J. Herzen, J. P. LoyolaRodriguez, and M. Epple, "Mineral distribution in highly fluorotic and in normal teeth: a synchrotron microcomputer tomographic study," Materialwissenschaft und Werkstofftechnik, vol. 40, no. 4, pp. 294-296, 2009.

[76] L. M. Marin, J. A. Cury, L. M. Tenuta, J. E. Castellanos, and S. Martignon, "Higher fluorosis severity makes enamel less resistant to demineralization," Caries Research, vol. 50, no. 4, pp. 407-413, 2016.

[77] B. Ogaard, "Effects of fluoride on caries development and progression in vivo," Journal of Dental Research, vol. 69, pp. 813-819, 1990.

[78] S. V. Dorozhkin, "Calcium orthophosphates (CaPo4) and dentistry," Bioceramics Development and Applications, vol. 6, no. 96, 2016.

[79] K. Kani, M. Kani, A. Isozaki, H. Shintani, T. Ohashi, and T. Tokumoto, "Effect of apatite-containing dentifrices on dental caries in school children," Journal of Dental Health, vol. 39, no. 1, pp. 104-109, 1989.

[80] U. Schlagenhauf, K.-H. Kunzelmann, C. Hannig et al., "Microcrystalline hydroxyapatite is not inferior to fluorides in clinical caries prevention: a randomized, double-blind, noninferiority trial," bioRxiv, 2018.

[81] K. Najibfard, K. Ramalingam, I. Chedjieu, and B. T. Amaechi, "Remineralization of early caries by a nano-hydroxyapatite dentifrice," Journal of Clinical Dentistry, vol. 22, no. 5, pp. 139-143, 2011.

[82] A. Kensche, C. Holder, S. Basche, N. Tahan, C. Hannig, and M. Hannig, "Efficacy of a mouthrinse based on hydroxyapatite to reduce initial bacterial colonisation in situ," Archives of Oral Biology, vol. 80, pp. 18-26, 2017.

[83] I. Harks, Y. Jockel-Schneider, U. Schlagenhauf et al., "Impact of the daily use of a microcrystal hydroxyapatite dentifrice on de novo plaque formation and clinical/microbiological parameters of periodontal health. A randomized trial," PLoS One, vol. 11, article e0160142, 2016.

[84] C. Hannig, S. Basche, T. Burghardt, A. Al-Ahmad, and M. Hannig, "Influence of a mouthwash containing hydroxyapatite microclusters on bacterial adherence in situ," Clinical Oral Investigations, vol. 17, no. 3, pp. 805-814, 2013.

[85] C. Palmieri, G. Magi, G. Orsini, A. Putignano, and B. Facinelli, "Antibiofilm activity of zinc-carbonate hydroxyapatite nanocrystals against Streptococcus mutans and mitis group Streptococci," Current Microbiology, vol. 67, no. 6, pp. 679681, 2013.

[86] S. A. Hegazy and I. R. Salama, "Antiplaque and remineralizing effects of Biorepair mouthwash: a comparative clinical trial," Pediatric Dental Journal, vol. 26, no. 3, pp. 89-94, 2016.

[87] M. Lelli, M. Marchetti, I. Foltran et al., "Remineralization and repair of enamel surface by biomimetic Zn-carbonate hydroxyapatite containing toothpaste: a comparative in vivo study," Frontiers in Physiology, vol. 5, p. 333, 2014. 
[88] J. Li, X. Xie, Y. Wang et al., "Long-term remineralizing effect of casein phosphopeptide-amorphous calcium phosphate (CPP-ACP) on early caries lesions in vivo: a systematic review," Journal of Dentistry, vol. 42, no. 7, pp. 769-777, 2014.

[89] D. L. Bailey, G. G. Adams, C. E. Tsao et al., "Regression of post-orthodontic lesions by a remineralizing cream," Journal of Dental Research, vol. 88, no. 12, pp. 1148-1153, 2009.

[90] P. Shen, D. J. Manton, N. J. Cochrane et al., "Effect of added calcium phosphate on enamel remineralization by fluoride in a randomized controlled in situ trial," Journal of Dentistry, vol. 39, no. 7, pp. 518-525, 2011.

[91] N. Gupta, C. Mohan Marya, R. Nagpal, S. Singh Oberoi, and C. Dhingra, "A review of casein phosphopeptide-amorphous calcium phosphate (CPP-ACP) and enamel remineralization," Compendium of Continuing Education in Dentistry, vol. 37, no. 1, pp. 36-39, 2016.

[92] Y. Wang, J. Li, W. Sun, H. Li, R. D. Cannon, and L. Mei, "Effect of non-fluoride agents on the prevention of dental caries in primary dentition: a systematic review," PLoS One, vol. 12, no. 8, article e0182221, 2017.

[93] J. M. ten Cate, "The need for antibacterial approaches to improve caries control," Advances in Dental Research, vol. 21, no. 1 , pp. 8-12, 2009.

[94] J. Enax and M. Epple, "Die charakterisierung von putzkörpern in zahnpasten," Deutsche Zahnärztliche Zeitung, vol. 73, pp. 116-124, 2018.

[95] C. H. Splieth, M. Alkilzy, J. Schmitt, C. Berndt, and A. Welk, "Effect of xylitol and sorbitol on plaque acidogenesis," Quintessence International, vol. 40, no. 4, pp. 279-285, 2009.

[96] M. B. Kowash, A. Pinfield, J. Smith, and M. E. Curzon, "Effectiveness on oral health of a long-term health education programme for mothers with young children," British Dental Journal, vol. 188, no. 4, pp. 201-205, 2000.

[97] M. Yaacob, H. V. Worthington, S. A. Deacon et al., "Powered versus manual toothbrushing for oral health," Cochrane Database of Systematic Reviews, vol. 6, 2014.

[98] M. Muller-Bolla and F. Courson, "Toothbrushing methods to use in children: a systematic review," Oral Health \& Preventive Dentistry, vol. 11, no. 4, pp. 341-347, 2013.

[99] P. M. Glaze and A. B. Wade, "Toothbrush age and wear as it relates to plaque control," Journal of Clinical Periodontology, vol. 13, no. 1, pp. 52-56, 1986. 


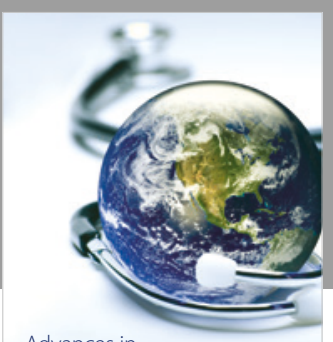

Advances in
Public Health

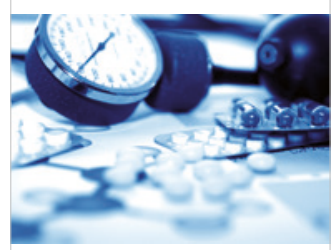

Case Reports in

Medicine

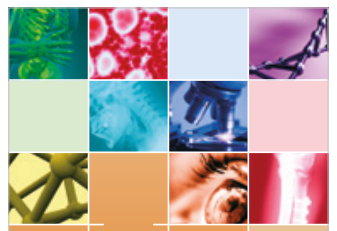

niernational Journal of

Biomaterials
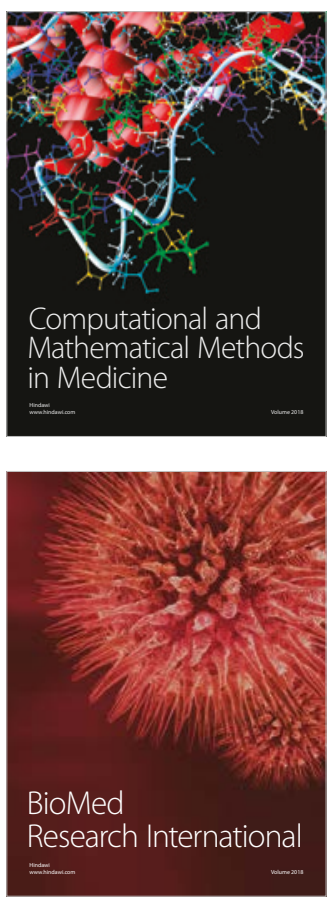

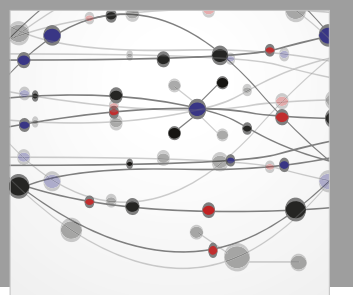

The Scientific World Journal Dentistry

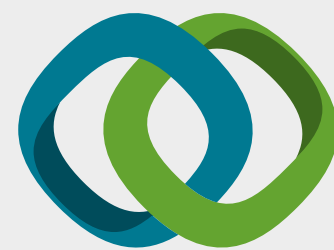

Hindawi

Submit your manuscripts at

www.hindawi.com
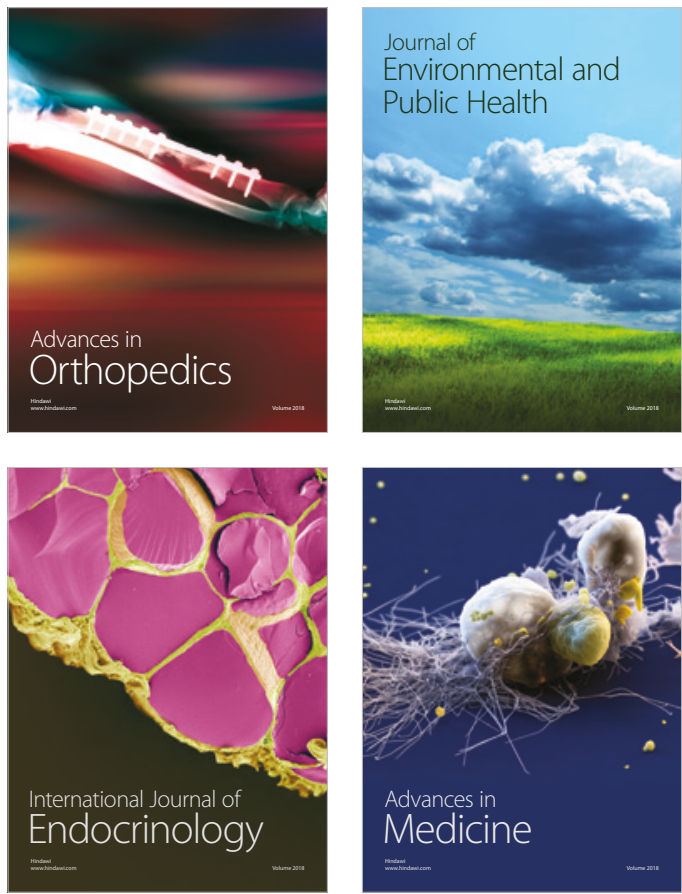
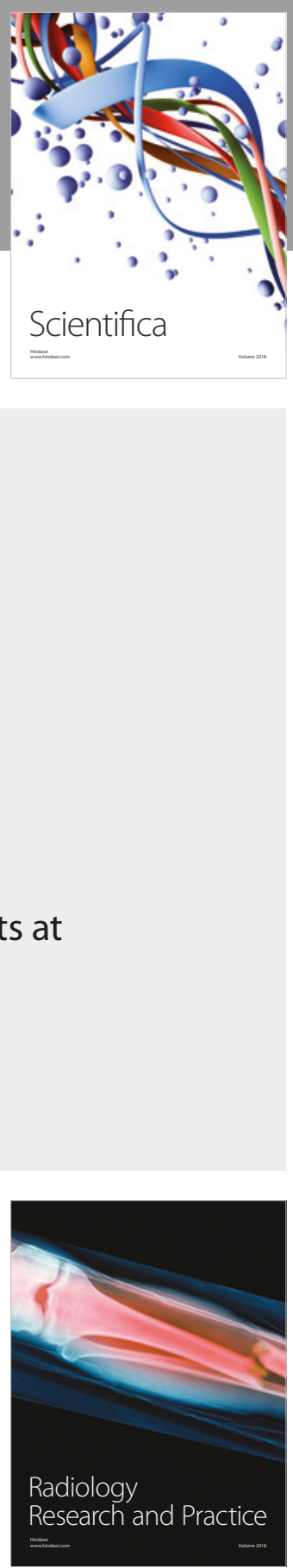

Scientifica

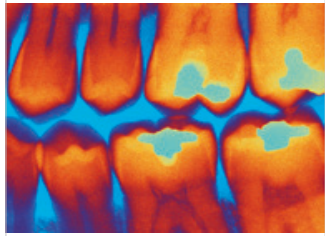

Case Reports in

Dentistry
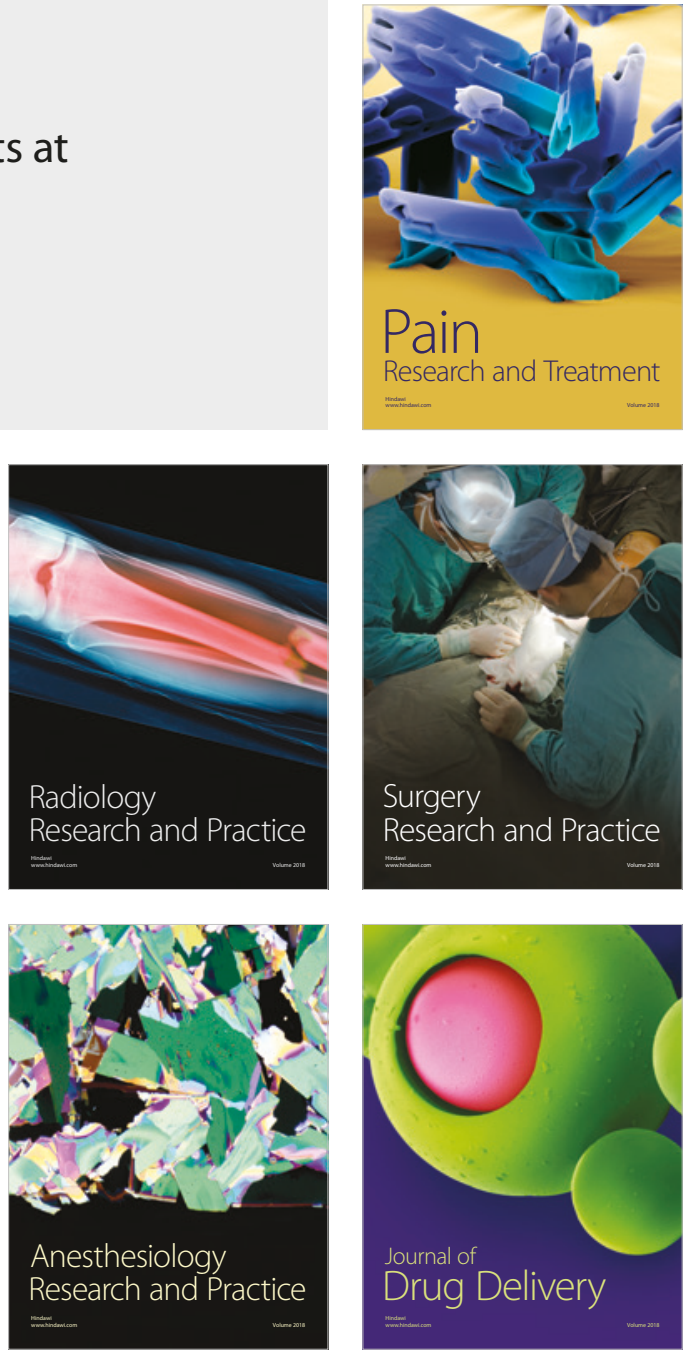